\title{
G Protein-Coupled Receptor Kinase 4
}

National Cancer Institute

\section{Source}

National Cancer Institute. G Protein-Coupled Receptor Kinase 4. NCI Thesaurus. Code C26232.

G protein-coupled receptor kinase $4(578 \mathrm{aa}, \sim 67 \mathrm{kDa}$ ) is encoded by the human GRK4 gene. This protein is involved in the phosphorylation of $\mathrm{G}$ protein-coupled receptors. 